\title{
WEAKNESSES OF THE POPULATION IN FERGANA REGION - PROBLEMS OF SOCIAL PROTECTION OF PERSONS WITH DISABILITIES
}

\author{
Tolipov Bekzod \\ Researcher, \\ Fergana State University \\ Fergana, \\ Uzbekistan
}

Article D0I: https://doi.org/10.36713/epra2517

\begin{abstract}
This article analyzes the issues of improving effective social assistance for vulnerable groups. Another topical issue today is the education and upbringing of children with disabilities who are not covered by education, the identification of objective and subjective reasons for their isolation in such a society, and the elimination of problems.
\end{abstract}

KEYWORDS: social protection, strategy, pension, person with disabilities, rehabilitation, correction

\section{DISCUSSION}

Mankind has always encountered people with disabilities, both physically and mentally, throughout its history. Attitudes toward them also varied at different stages of development. According to the Law of the Republic of Uzbekistan «On Social Protection of Persons with Disabilities in the Republic of Uzbekistan», a person with a disability in the manner prescribed by law due to limited physical activity due to physical, mental, mental or sensory (sensory) defects and in need of social assistance and protection. Limitation of a person's life activities means that a person has completely or partially lost the ability or ability to self-serve, move, find a way, communicate, control his behavior, as well as study and work. The word is derived from the Latin word invalidus, which means «weak, not strong», i.e. in «not» + validus - «strong», in other words, it is used in the activities of a person with physical, mental, sensory or mental disabilities. indicates an existing obstacle or restriction.

It is known that in the social policy of Uzbekistan, medical and social rehabilitation of persons with disabilities is considered a topical issue. The Action Strategy for the further development of Uzbekistan is also based on the ideas of populism, humanity, tolerance and kindness. It is based on the theory that the harmony of national and universal values is a priority in the assessment and approach to social, political and economic processes [1.9]. As of
January 2020, the number of disabled people in need of general rehabilitation equipment and prosthetic and orthopedic products in Fergana region is 7325 people. To date, 3,914 needy people with disabilities have been provided with rehabilitation equipment and prosthetic and orthopedic products, and the remaining 3,914 are planned to be provided in stages this year.

The importance of social protection can be understood in the Fergana region, although attention is paid to information about war veterans and the disabled in 1941-1945, veterans of frontline labor, old-age pensioners and people with disabilities in need of rehabilitation equipment and prosthetic and orthopedic devices [2].

The head of our state is also working to provide social protection to the needy, to ensure that they are not cut off from social life. «The implementation of the approved program of state support for the elderly and nogrophons should be under special control. Every privilege and measure of social protection must reach its owners» [3.253].

The scientific analysis of the level of health in families and the socio-hygienic situation in the family shows that a lot of work is being done in our country to improve reproductive health, prevent births with birth defects and diseases, strengthen the material and technical base and human resources of medical institutions. If relevant, the health, social and medical-hygienic status of the family raising a 
disabled child, rehabilitation, rehabilitation and improvement of correctional and pedagogical work in the family is also the most important task today [4.12]. One of the most pressing issues today is the education and upbringing of children with disabilities who are not covered by education, to identify the objective and subjective reasons for their isolation in such a society, and to address the problems. Today, 84 special schools and boarding schools operate in the country under the Ministry of Public Education. State legislation also addresses the issue of involving children in homeschooling, taking into account the wishes of parents, in particular, children with disabilities are educated on the basis of individual home-based education programs. Also, as of February 2020, there are 3 «Muruvvat» houses and 1 «Sakhovat» houses in Fergana region.

It is known that not all developmental defects and disorders occur in infancy. Most of these changes can be detected at an older age. They are often manifested in the example of defects of the nervous system, auditory and visual organs, as well as speech. Research has shown that the earlier children with physical and mental disabilities are treated, the sooner their deficiencies will be corrected or corrected.

Of course, peace and health in the family is a blessing, if there is a problem with the health of the child in the family, the parent will be in a difficult situation. If the newborn has a clear physiological or mental weakness, the mother is the first person who can create the necessary conditions for him and only with patience, understanding, kindness, love can help him, while directing him to future education and most importantly his «Muruvvat» in good conscience. However, for this it is necessary to work on himself and deeply study the child. When a parent is depressed, he loses interest in any activity, even for a short time. They try to avoid people, to cut ties with their old loved ones. In this case, mothers need help in managing how to communicate with a sick child.

Today, it is very important that families with children with disabilities are supported by members of our community. Because families with children with disabilities have their own psycho-emotional experiences, these families often naturally lose or give up their jobs because of their children with disabilities, unable to take an active part in public affairs, leading to isolation. In addition, many parents try to hide the fact that they have children with disabilities. In some cases, children are not sent to school when they reach school age. As a result, such children are not covered by any education. In everyday life, we also see families who abandon their children with disabilities altogether and send them to «Muruvvat» homes or orphanages. In fact, since a child with a disability has the same right to education as any other child as a full member of society, it is important to keep in mind at all times that parents are particularly interested in this. Such families should be supported in every way. In particular, if jobs are created for parents with children with disabilities not far from home, we believe that this is the most compassionate assistance provided to such families, and it would be one of the important factors in ensuring that a disabled child does not fall into Muruvvat» house.

As parents are primarily responsible for the education of children with special needs, they must be able to communicate with children with disabilities in a special way, be aware of the methods of raising a child with disabilities, and know the simplest skills to help a child prepare for school.

As part of the study, a survey was conducted among students of the Republican Vocational College for Persons with Disabilities in Fergana. The purpose of the study was to determine the interests of students currently studying in specialized educational institutions for people with disabilities, as well as their focus on specialties within their interests, awareness of information technology. A total of 105 respondents took part in the survey, of which 51 were boys and 54 were girls.

It turned out that 70 students of this vocational college came from different districts and cities of Fergana region, while 35 students came from other regions. In the 2019-2020 academic year, students of the Republican Vocational College for Persons with Disabilities in Fergana are preparing for a career in a total of 7 areas. In particular, students from different regions of the country study at the college in the areas of «Accounting and Auditing», «Sewing», «Computer Technology», «Craftsmanship», «Radio Engineering», «Craftsmanship», «Library». It turned out that the most popular among college students is in the field of "Accounting and Auditing. The college has created favorable conditions for the education of young people, sports grounds for students, laundry and dining rooms are in demand. They also organized clubs in different directions during their extracurricular activities.

During the study, we saw that young people with disabilities who want to study in a specialized college for people with disabilities are forced to be content with the existing directions in the educational institution, as well as their need for training in entrepreneurship. Indeed, teaching small business and private entrepreneurship to people with disabilities is beneficial. In the future, they may become entrepreneurs in various innovative areas. This will ensure their employment, as well as the possibility that the person with the disability will run a business in trade or services on the basis of the specialty in which he is studying.

In our country, in the early detection of disabilities and their preparation for school, special attention should be paid to the placement of children 
in preschool institutions. This helps in early detection of defects in children, as noted above. If the number of preschools was further increased on the basis of an inclusive education program, or special groups were established within existing preschools, this would certainly be one of the most successful ways to integrate children with disabilities into healthy children. From the earliest stages of the formation of such children's thinking, they developed the ability to teach and nurture themselves (stigma) not to avoid others and to feel free. By communicating with the parents of such children, it was possible to jointly develop their children's mastery and increase their correctional and pedagogical literacy. Children with disabilities will inevitably develop a desire to attend public school when they reach school age, without being separated from their families like other children.

\section{Адабиётлар руйххати}

1. М.Бекмуродов,Қ.Куронбоев,

Л.Тангриев.Харакатлар

Стратегияси асосида жадал тараққиёт ва янгиланиш сари. Тошкент.: Ғафрур Ғулом. 2017. -Б.9.

2. Фарғона вилояти Соғлиқни сақлаш бошқармаси маълумотлари асосида тайёрланди.

3. Мирзиёев Ш.М. Миллий тараққиёт йўлимизни қатъият билан давом эттириб, янаи босқичеа кўтарамиз.- Тошкент: «Ўзбекистон», 2017, 1-том, -Б. 253.

4. Ш.М.Мирзиёев. Қонун устуворлиги ва инсон манфраатларини таъминлаш - юрт тараққиёти ва халқ фраровонлиги гарови. Тошкент. Ўзбекистон. 2017 йил. Б. 12 . 